CUBA AND THE POLITICS OF PASSION 
Damián J. Fernández

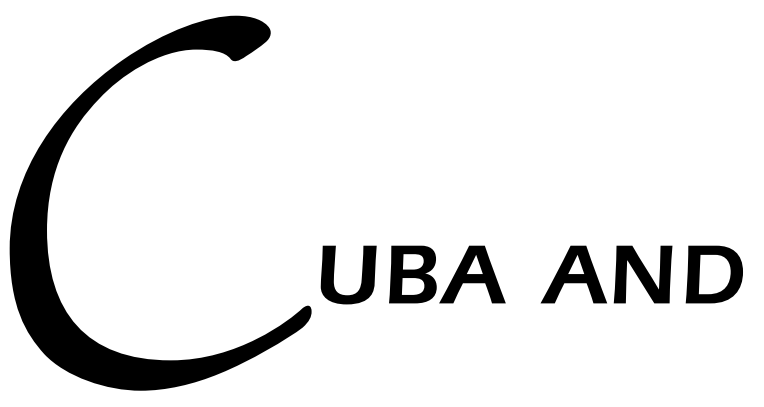




\section{THE POLITICS OF PASSION}

$\underset{1}{ }$ University of Texas Press, Austin 
Copyright (C) 2000 by the University of Texas Press
All rights reserved
Printed in the United States of America

First edition, 2000

Requests for permission to reproduce material from this work should be sent to Permissions, University of Texas Press, Box 7819, Austin, TX 78713-78I9.

(2) The paper used in this book meets the minimum requirements of ANSI/NISO Z39.48-I992 (RI997) (Permanence of Paper).

Library of Congress Cataloging-in-Publication Data Fernández, Damián J.

Cuba and the politics of passion / Damián J.

Fernández

p. $\mathrm{cm}$.

Includes bibliographical references and index.

ISBN 0-292-725I9-I (alk. paper) -

ISBN 0-292-72520-5 (pbk. : alk. paper)

I. Political culture-Cuba. 2. Cuba-Politics and government. I. Title.

JLIOIO .F47 2000

306.2'09729I-dc2I

00-024I53 